\title{
OBSOLETE PESTICIDES: THEIR ENVIRONMENTAL AND HUMAN HEALTH HAZARDS
}

\author{
Binod P Shah (MSC) ${ }^{1}$ and Bhupendra Devkota $(\mathrm{PhD})^{2}$
}

\begin{abstract}
UN FAO estimates that half a million tonnes of obsolete pesticides are in storage world-wide. In Nepal there are 74.5 metric tonnes of obsolete pesticides stored in warehouses in many places of the country. Many stocks are located near farm fields, human settlements, schools or water sources. Lack of health related studies and very limited studies on environmental contamination by obsolete pesticides led to undertake this study, which focuses on health and environmental impacts of obsolete pesticides stored in a warehouse at Amlekhgunj, Bara district, Nepal. The present study found an interrelation between the pesticide residue level in soil samples of a nearby school-ground and the health impacts seen on the students of the same school.
\end{abstract}

The government and concerned agencies should take out the initiatives to quick and safe disposal of obsolete pesticides and also take care that no new stock will be accumulated in the future.

Key words: Obsolete pesticides, soil contamination, health effects.

\section{INTRODUCTION}

Traditionally, farming in Nepal was organic in nature and was therefore, ecologically sound and sustainable for human beings and other living organisms. Until the 1950s, Nepali farmers were unaware of agro-chemicals. They were dependent upon their rich traditional wisdom to control pests. The use of agrochemicals such as fertilizers and pesticides started with the growth of population and transfer of traditional farming to modern agriculture with the establishment of the department of Agriculture Development (DOA) in the early 1960 s.

There is discrepancy among published literatures and data as to the exact date of pesticides' first entry into Nepal. One report states that chemical pesticides were first introduced in 1955 when paris green, gamaxene and nicotine sulphates were imported from the United States for malaria control, and that DDT was first introduced in 1956 (WWF, 1995). Another report states that the first appearance of DDT in Nepal came in 1952 when 800 houses were sprayed in an effort to protect people from malaria (Kandel and Mainali, 1993). Regardless of the exact date, persistent pesticides were first introduced into Nepal in the form of DDT, which was used for malaria eradication. Department of Agriculture (DOA) initiated the use of chemical pesticides in agricultural sector to protect the crops from plants' disease and pest attack only after the second half of 1960s. Use of pesticides has definitely helped to improve health condition of people as well as to increase agricultural productivity, but it has also created several long-lasting side effects on human health and environment.

Pesticide exposure can have chronic and acute impacts on human health. Long term low dose exposure to pesticide causes immune suppression, hormonal disruption, diminished intelligence, reproductive abnormalities and cancer (Gupta, 2004).

Soil and groundwater pollution are the main environmental effects of pesticides. However, there are evidences that many species of insects, mammals and birds (Manandhar 2006) 
have been affected.

Pesticides in soils become toxic to arthropods, earthworms, fungi, bacteria, and protozoa which are vital to ecosystems, because they dominate both the structure and function of natural system (Pimentel et.al 1992).

\section{OBSOLETE PESTICIDES}

Another problem which occurs due to pesticide is the conversion of pesticides into the obsolete form, which may even show more harmful effects than the former.. When the pesticides are not used within the prescribed time of their efficacy, they become obsolete. "Obsolete pesticides" are defined as those pesticides that can no longer be used for their intended purpose or wanted to be used and therefore must be disposed off. They are decomposed into other chemical components, which are sometimes even more toxic than the original pesticides. Most pesticides expire two years after production, meaning they cannot be used unless they are tested and proved stable.

In Nepal, there is a stockpile 74.5 MT of the obsolete pesticides, majority of which belong to banned POPs pesticides, the "Dirty Dozen" under Stockholm Convention and are stored in 24 locations/warehouses across the country for more than 30-40 years. In Nepal such a huge amount of obsolete pesticides was due to the inappropriate donations from the donor agencies/countries and over-purchasing in the past. The condition of the stocks is highly variable. Some include products that are still viable and could be reformulated and repackaged for use (although the cost might be prohibitive). Other stocks consist of unprotected and unidentifiable mounds of mixed products, corroding containers and contaminating soils (MOEST 2006). Many stocks are located near farm fields, human settlements, schools or water sources, as the pesticides were stored close to where they were to be used. Many stocks are abandoned, unmanaged, have no labels, and have no clear "owner" to be responsible (Manandhar 2006). In most cases, such stocks would be classified as hazardous waste under international law and controlled by the Basel Convention if subject to transboundary movements.

\section{STATEMENT OF PROBLEM}

Of the 74.5 MT of obsolete pesticides stored in different ware house/stores in Nepal, Amlekhgunj is the major warehouse containing 50.90 MT of pesticides packed in 200 liter steel drums and 60 liter HDPC (MOEST 2006). These consists of POPs, pesticides 28.10 MT, organomercury 7.40 MT, organ chlorine 7.3 MT, organophosphate $1.20 \mathrm{MT}$, fungicides 2.50 MT, rodenticides 1.0 MT, fumigants 2.0 MT herbicides 1.40 MT. Due to huge amount of unsafe storage and leakage of obsolete pesticide in the past, there is great probability of environmental contamination as well as human health problems (mostly the school children near the warehouse). According to the report of Pro Public (2005), five composite samples from the school ground adjacent to Amlekhgunj warehouse $\mathrm{HCH}$, DDD, DDE, DDT, Dieldrins, Chlorpyrifos were detected; also mercury was present in 4 samples. So there is high chance that the school children, teachers and staffs might have been affected by the soil and air contamination and needs proper assessment and verification.

\section{OBJECTIVE OF THE STUDY}

The objective of this study was to know the level of soil contamination by the leakage of obsolete pesticides around the warehouse and its health impacts on the school children of Shree Nepal Secondary School, Amlekhgunj, Bara District. 


\section{MATERIALS AND METHODS}

Amlekhgunj Warehouse and Shree Nepal Madhayamik Vidhayalya were selected as the study area, which lie in the Ward No.1 of Amlekhgunj VDC, Bara District, Nepal. It is about $50 \mathrm{~km}$ North of Birgunj on the way to Kathmandu along the Mahendra Highway.

Shree Nepal Madhayamik Vidhayalya is a government owned secondary school, which lies adjacent to the warehouse, where 50.9 MT obsolete pesticides are stored. The west wall of the warehouse and the school playground are adjacent to each other. This is the biggest school in the area having around 1000 students.

Seven composite soil samples were collected from the school ground at every meter $(1,2$, 3 and $4 \mathrm{~m}$ in the south and 0,1,2 $\mathrm{m}$ in the north) from the wall of the warehouse. The soil samples were taken to Pollution Monitoring Laboratory (PML), New Delhi, India, where the analysis of 26 different types of pesticide residues (16 organochlorines, 10 organophosphates and one heavy metal $\mathrm{Hg}$ ) in the soil was done. PML is known to follow the internationally used methodology prescribed by United States Environment Protection Agency (USEPA) for organochlorine and organophosphorus pesticides detection.

The semi-structured questionnaires survey was done to collect the information on the health hazards of the students, teachers and the villagers.

\section{RESULTS AND DISCUSSION}

\section{HEALTH IMPACTS}

The study showed that the majority of the school children were from poor family background and most of the parents/guardians were daily wage workers, who were not able to bear huge cost for any catastrophes. As the school children, aged between 3 to 15 years, were in their tender ages, they were among the most vulnerable ones to the contaminants of obsolete pesticides.

The main entrance of the school was directly attached to the warehouse and due to the closeness with the warehouse the staffs and students were feeling very strong smell of pesticides, especially during the time of high temperatures and rainy season. Due to constant exposure they had become used to to such level of smell and could not even feel the strong smell, which the new visitors could feel in the very first exposure.

Moreover, the smell was strong during daytime and very strong during the noon, probably due to the high temperatures of those hours. The exposed ones had reported the cases of irritation, dizziness and decreasing working efficiency and less concentration at work or study. Nearly half of the children did not attend regular classes to avoid constant exposures, but appeared only in the examinations. It had thus great impact on the quality of education.

On the other hand the parents did not have better alternatives other than to send their children to this school. Study showed that $95 \%$ of pupil of the school claimed the problem to be due to the storage of obsolete pesticides in the adjoining warehouse. Along with the available scanty health data, the behavior of students and their level of study efficiency was compared with such qualities/ parameters of the students from other school of the same grades and it was found that the students of Shree Nepal Madhayamik Vidhayalya showed symptoms of some sort of pesticide contamination. The following health risks (Table 1) were obtained among the students of the school. 
Table 1. Different health effects observed in the students (in percentage)

\begin{tabular}{|l|l|}
\hline Health effects & Result (\%) \\
\hline Headache & 90 \\
\hline Vomiting & 10 \\
\hline Heart complaint & 4 \\
\hline Foul smell & 100 \\
\hline Unconsciousness & 10 \\
\hline Drowsiness & 72 \\
\hline Irritation & 50 \\
\hline Eye problem & 33 \\
\hline Skin problem & 24 \\
\hline Loss of concentration & 75 \\
\hline
\end{tabular}

SOIL

The soil showed the evidences of high contamination in the school ground adjacent to the warehouse. Among 16 organochlorines and 10 organophosphates pesticides, all 26 could not be detected in the soil samples; the detected pesticides including a heavy metal $\mathrm{Hg}$ are presented in Table 2. Higher concentration of pesticides and heavy metals were detected in the soil samples from the north side of warehouse.

Table 2. Pesticides and heavy metal concentrations $(\mathrm{mg} / \mathrm{kg})$ in soil samples from the school playground at Amlekhgunj (2008): Present study

\begin{tabular}{|c|c|c|c|c|c|c|c|c|c|}
\hline \multirow{2}{*}{$\begin{array}{l}\text { S. } \\
\text { No }\end{array}$} & \multirow[t]{2}{*}{ Pesticide } & \multirow[t]{2}{*}{ Class } & \multicolumn{3}{|c|}{ North } & \multicolumn{4}{|c|}{ South } \\
\hline & & & $0 \mathrm{~m}$ & $1 \mathrm{~m}$ & $2 m$ & $1 \mathrm{~m}$ & $2 m$ & $3 m$ & $4 m$ \\
\hline 1 & a- $\mathrm{HCH}$ & Oc & 0.0013 & 0.0009 & 0.3617 & 0.0007 & ND & ND & ND \\
\hline 2 & $\mathrm{~B}-\mathrm{HCH}$ & Oc & 0.0014 & ND & 1.2566 & 0.0018 & ND & ND & ND \\
\hline 3 & $\gamma-\mathrm{HCH}$ & & 0.0412 & 0.0135 & 0.7684 & ND & 0.0080 & 0.0252 & ND \\
\hline 4 & Heptachlor & Oc & 0.0029 & 0.0016 & 0.3925 & ND & 0.0036 & 0.0048 & 0.0034 \\
\hline 5 & Aldrin & Oc & ND & ND & 0.3613 & ND & ND & ND & ND \\
\hline 6 & phosphamidon & Op & ND & ND & 1.0728 & ND & ND & ND & 0.0094 \\
\hline 7 & a -endosulfan & Oc & 0.0158 & 0.0044 & 0.7537 & 0.0011 & ND & ND & ND \\
\hline 8 & cis chlordane & Oc & ND & ND & ND & 0.0502 & 0.0440 & 0.0565 & ND \\
\hline 9 & trans chlordane & Oc & 0.0137 & 0.0020 & 0.3885 & ND & ND & ND & ND \\
\hline 10 & DDE & Oc & 0.0300 & 0.0175 & 0.3378 & 0.0013 & 0.0119 & 0.0145 & 0.0139 \\
\hline 11 & Dieldrin & Oc & 0.0407 & 0.0111 & 1.0076 & ND & ND & ND & 0.0016 \\
\hline \multirow[t]{2}{*}{12} & DDD & Oc & 0.0328 & 0.0161 & 0.2460 & ND & 0.0155 & 0.0125 & 0.0128 \\
\hline & Heavy Metal & & & & & & & & \\
\hline 13 & Mercury & $\begin{array}{l}\text { Heavy } \\
\text { Metal }\end{array}$ & 3.4600 & 1.8700 & 1.6090 & ND & ND & 3.4250 & 2.4110 \\
\hline
\end{tabular}

Note: Oc - Organochlorine. Op - Organophosphorus; ND - not detected 
Among 16 Organochorines analysed, DDE (most persistent metabolite of DDT) was detected in all seven samples. $\delta-\mathrm{HCH}$, DDT, and B-endosulfan, were not detected in any sample. Among 10 Organophosphorus pesticides, only phosphamidon was detected in two samples. Mercury was detected in five of the seven soil samples.

Very few studies were conducted in the past on the pesticide residues in the contaminated soil. A similar study done by Pro-Public in the year 2005 (MOEST 2007) showed significant level of pesticides contamination in the same site by taking only 5 composite soil samples. The Pro-Public, an NGO, did not study the relation between the health impacts and soil contamination at that time. However, the result of the present study when compared with the findings of the Pro-Public, an increase in some pesticides residues i.e a-endosulphan and mercury in the soil but in the meantime a decrease of DDD could be found. The residues of some pesticides i.e. $-\mathrm{HCH}$ had disappeared, whereas the new ones like heptachlor, cis and trans chlordane appeared in the soil.

Table 3. Pesticides and heavy metal concentrations $(\mathrm{mg} / \mathrm{kg})$ in soil samples from the school playground at Amlekhgunj (2005): Pro-Public study

\begin{tabular}{|c|c|c|c|c|c|c|}
\hline S.No & Pesticides & $0 \mathrm{~m}$ & $1 \mathrm{~m}$ & $2 m$ & $3 m$ & $4 \mathrm{~m}$ \\
\hline 1. & a- $\mathrm{HCH}$ & n.d. & n.d. & n.d. & n.d. & n.d. \\
\hline 2. & $\mathrm{~B}-\mathrm{HCH}$ & n.d. & n.d. & 0.002 & n.d. & n.d. \\
\hline 3 & $\gamma-\mathrm{HCH}$ & 0.0920 & 0.0964 & 0.1065 & 0.0833 & 0.0792 \\
\hline 4. & $\delta-\mathrm{HCH}$ & 0.0091 & 0.0091 & 0.0020 & n.d. & n.d. \\
\hline 5. & Heptachlor & n.d. & n.d. & n.d. & n.d. & n.d. \\
\hline 6. & Chlordane & n.d. & n.d. & n.d. & n.d. & n.d. \\
\hline 7. & DDD & 0.2112 & 0.0138 & 0.0189 & 0.0692 & 0.2614 \\
\hline 8. & $\mathrm{DDE}$ & 0.0529 & 0.0260 & 0.0423 & 0.0262 & 0.0773 \\
\hline 9. & DDT & 06397 & .012749 & 0.0858 & 0.9475 & 9.4621 \\
\hline 10. & Dieldrin & 0.0040 & 0.0040 & 0.00402 & 0.0029 & 0.0030 \\
\hline 11. & Aldrin & n.d. & n.d. & n.d. & n.d. & 0.0147 \\
\hline 12. & a- endosulphan & 0.00088 & n.d. & n.d. & n.d. & n.d. \\
\hline 13. & B- endosulphan & n.d. & n.d. & n.d. & n.d. & n.d. \\
\hline 14. & Endosulphan sulphate & n.d. & n.d. & n.d. & n.d. & n.d. \\
\hline 15. & Methoxychlor & n.d. & n.d. & n.d. & n.d. & n.d. \\
\hline 16. & Chlorpyrifos & 0.0021 & .0091 & 0.0050 & 0.0047 & 0.0061 \\
\hline
\end{tabular}

(Source: MOEST 2007)

\section{CONCLUSION}

Pesticide residues, some of which even belong to POPs category, in the soil near the warehouse were found having adverse impacts on the human health and environment of the study area. The constant presence of such pesticides over a long time or even increasing level of some obsolete pesticides in the soil confirmed that the pesticides had persistence nature and their concentrations in the soil was increasing with time along with the potential of increasing health hazards. Among the students, 95\% related their health problems to the soil contaminants of pesticides in the adjoining warehouse. If obsolete pesticides stored in Amlehkganj Warehouse, will not be disposed off safely in time, 
unavoidable accidents may aggravate the problem in the future. Since the pesticides have the property of bioaccumulation and biomagnifications, they will derive long lasting impacts on the environment and human health; especially the students need to be protected in time. Students spending 180 days in the school come in contact with such pesticides in soil or air for 1080 hours in a year and this is enormously high occupational exposure to any contaminant. An exposure of this degree at the growing and learning stage of the school children is actually a loss to the Nation. The complaints of the students indicated that there might be a significant level of these pesticides in their tissues, which needs to be verified by the future investigations. Moreover, similar research is also needed to be done in air samples to reach at the core of conclusions. Government needs to pay special attention towards the safer disposal of obsolete pesticides to protect the environment and public health and to ensure clean and healthy environment, which is the basic right of the citizen and the state is responsible to guarantee it.

\section{ACKNOWLEDGEMENT}

The financial support by the Ministry of Environment, Science and Technology (MOEST) for the conduction of this study is highly acknowledged.

\section{REFERENCE}

Gupta, P. K., 2004. Pesticide Exposure-Indian Scene, Toxicology, 198: 83-90.

Kandel, K.R. and Mainali, M., 1993. Playing with Poison. The Nepal Forum of Environment Journalist, Pesticides Watch Kathamadnu, Nepal, pp. 24-25.

Manandhar, D.N., 2006. Pesticides Use in Nepal.

MOEST, 2005. Inventory of pesticides in Nepal. POPs Enabling Activities Project, MOEST, Nepal.

MOEST, 2007. National Implementation Plan For The Stockholm Convention on Persistent Organic Pollutants. POPs Enabling Activities Project, MOEST, Nepal.

Pimentel, D.L. and McLaughlen. 1991. Environmental and economic impacts of reducing U.S. agricultural pesticide use. In: D.Pimentel and A.A. Hanson (Eds.) CRC Handbook of Pest Management in Agriculture. 2nd ed. vol I. CRC Press. Boca Raton, pp. 679-718.

Pimentel, D., 1992. Environment and Human Cost of Pesticides Use. Bioscience, 42: 740-760

World Health Organization (1990): Public Health Impact of Pesticides Used in Agriculture. WHO,Geneva.

WWF, 1995. Environmental Impact from Nepal's use of chemical Pesticides. World Wildlife Fund Report series\# 16, Kathmandu, Nepal.

WWF, 2005. Toxic Fact Sheet, World Wildlife Fund http://www.worldwildlife.org/toxics/ pubs.cfm 